\title{
REHABILITATION OF RC BUILDINGS IN SEISMICALLY ACTIVE REGIONS USING TRADITIONAL AND INNOVATIVE MATERIALS
}

\section{REHABILITACIJA ARMIRANOBETONSKIH (AB) KONSTRUKCIJA U SEIZMIČKIM USLOVIMA KORIŠĆENJEM TRADICIONALNIH I INOVATIVNIH MATERIJALA}

\author{
Golubka NECHEVSKA-CVETANOVSKA \\ Artur ROSHI
}

STRUČNI RAD PROFESSIONAL PAPER UDK:624.012.45.042.7 doi:10.5937/GRMK1903019N

\section{INTRODUCTION}

Behaviour of the structures constructed and built of reinforced concrete during their serviceability period as well as during earthquakes depends on many factors. On one hand, there are the external factors, i.e., loads acting upon the structures (in addition to the main loads, there are also additional loads as well as effects caused by possible explosions, fires, earthquakes), while on the other hand, there are the factors that directly depend on the very structure of the buildings (structural system, type, quality and quantity of material used for the construction of the structure, the number of storeys, the mode of foundation,....). All these factors directly affect the strength and deformation characteristics of the individual structural elements and the structural system as a whole.

The need for repair and strengthening of $\mathrm{RC}$ buildings and their structural elements occurs when their elements lack sufficient strength, stiffness and/or ductility out of different reasons or due to slighter or more severe damages most frequently caused by earthquakes.

It has been a usual practice to perform repair and strengthening of structures by application of traditional methods (most frequently, jacketing of elements), but lately, new innovative materials with a special technology of construction and repair have increasingly

Golubka Nechevska-Cvetanovska, Professor Doctor, PhD, Graduate civil engineer, University Ss.Dyril and Metodius, Institute of Earthquake Engineering and Engineering Seismology(IZIIS), Skopje, Macedonia, email: golubka@pluto.iziis.ukim.edu.mk Artur Roshi, PhD student-IZIIS-Skopje,Master of science, Graduate civil engineer, Metropolitan university, Tirana Albanija; email: artur.roshi@yahoo.com been applied. The application of these materials is still the subject of a large number of investigations worldwide, particularly in the field of application of these materials in seismically active regions.

\section{REPAIR AND STRENGTHENING OF BUILDINGS STRUCTURES}

\subsection{General}

Strengthening of reinforced concrete structural elements is one method to increase the earthquake resistance of damaged or undamaged buildings. The strength of the structures can be moderately or significantly increased and the ductility can be improved, or in other words, it can be said that the concept of strengthening involves: a) increase in strength, b) increase in strength and ductility and c) increase in ductility, (Figure 2.1).

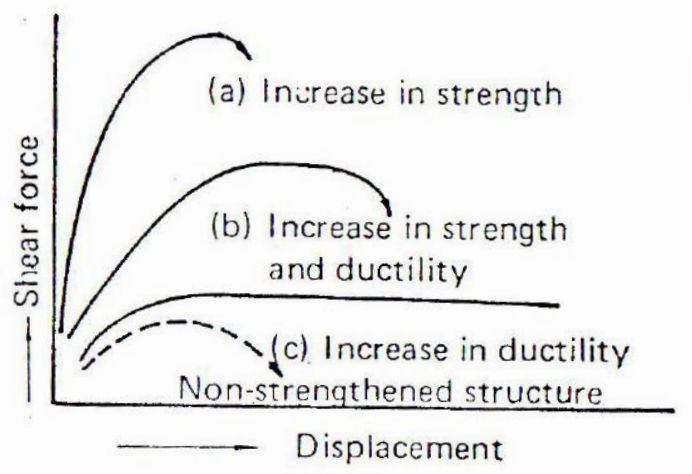

Figure 2.1. Concept of seismic strengthening 
The methods for repair and strengthening of buildings may basically be categorized into two main groups: system based repair and strengthening (Global Strengthening) and member based strengthening (Local Strengthening).

In the system based strengthening methods, a structural system is modified by adding members such as reinforced concrete shear walls or additional steel bracing, mainly improving the strength and stiffness characteristics of the system.

A new frame can be introduced to increase the lateral strength and stiffness of a building. Similar to a new wall, integrating a new frame building and providing foundations are critical design issues.

\subsection{Global strengthening methods}

In the system based strengthening methods, a structural system is modified by adding members such as reinforced concrete shear walls or additional steel bracing, mainly improving the strength and stiffness characteristics of the system.

Most of the strengthening strategies have recently been based on global strengthening schemes as per which the structure is usually strengthened for limiting lateral displacements in order to compensate the low ductility. In these methods causing a change in the global behaviour of the building, as explained above, a behavioural change takes place when new members are added to the building.

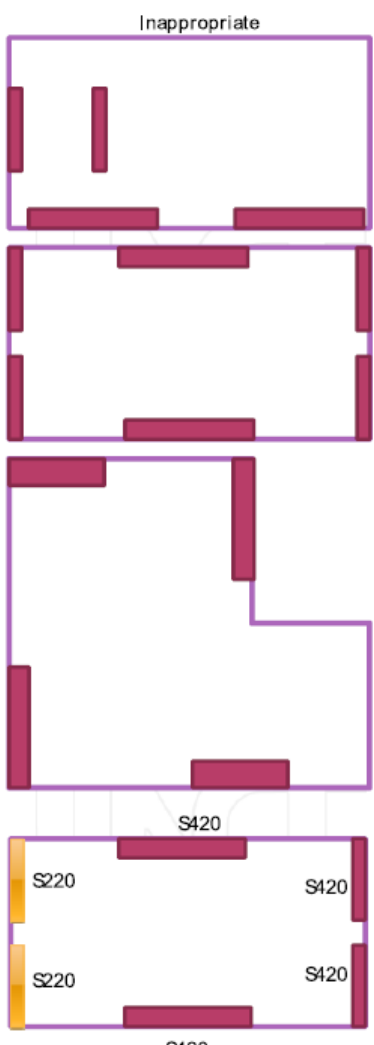

$\$ 420$
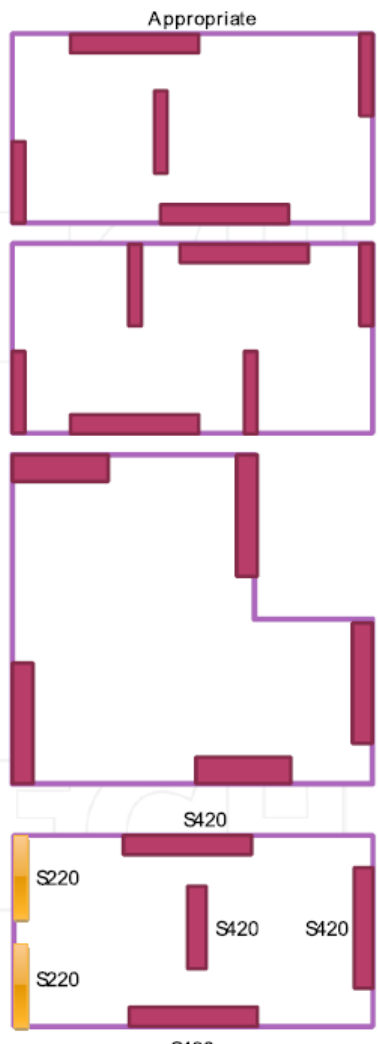

$\$ 420$

Fig.2.2. Inappropriate and appropriate shear walls layouts (Handbook,[10])
In order to be added to the structure, reinforced concrete walls should be placed in a manner that torsional effects on the structure are prevented and irregularities in the structure are eliminated, as observed in the design of new buildings. Some appropriate and inappropriate shear wall layouts are presented in Figure 2.2.

A steel bracing system can be inserted in a frame to provide lateral stiffness, strength, ductility, hysteretic energy dissipation, or any combination of these. The braces are effective for relatively more flexible frames, such as those without infill walls. The braces can be added to the exterior frames with least disruption of the building use. For an open ground storey, the braces can be placed in appropriate bays while maintaining the functional use. Passive energy dissipation devices may be incorporated in the braces. The connection between the braces and the existing frames is an important consideration of this strategy. One technique of installing braces is to provide a steel frame within the designated $\mathrm{RC}$ frame. The steel frame is attached to the $\mathrm{RC}$ frame by installing headed anchors. (Figure 2.3).

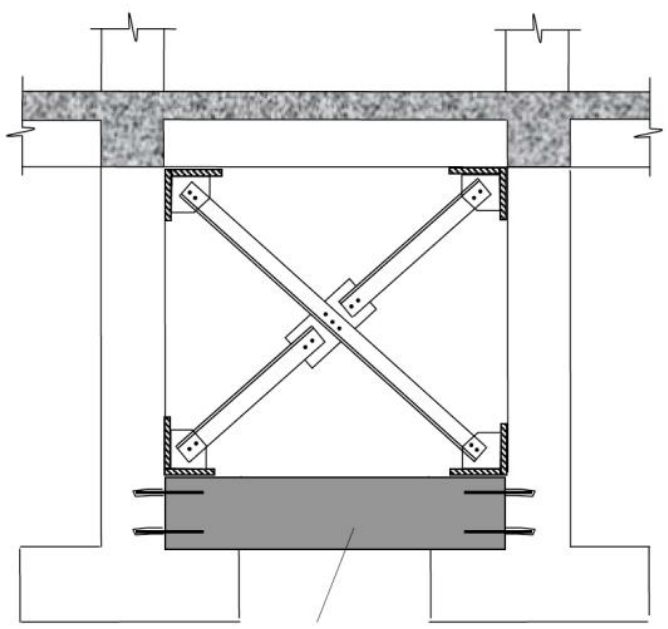

Figure 2.3. Additional steel braces

A new frame can be introduced to increase the lateral strength and stiffness of the building. Similar to a new wall, integrating a new frame building and providing foundations are critical design issues.

\subsection{Local strengthening methods}

The local strengthening approach involves modification of deficient elements to increase ductility so that the deficient elements will reach their limit states in a ductile manner when subjected to design events. However, this strategy is more expensive and harder to implement in cases of many deficient elements which is the reason that the global strengthening methods have been more popular than element strengthening. Effective results can be obtained by using such methods in buildings with a limited number of deficient elements along with the global strengthening methods. 


\subsubsection{RC jackets}

One of the most frequently used methods for strengthening reinforced concrete columns is reinforced concrete jacketing (Figure 2.4).

Jacketing, which can be defined as the confinement of the column with new and higher quality reinforced concrete elements may be implemented for various purposes based on the type of structural member deficiencies. Columns subjected to brittle damages can be jacketed in order to enhance resistance against shear and/or axial loads. In that case, although the purpose of jacketing is only to increase axial load or shear strength, some changes will also occur in the bending stiffness and moment capacity of the member after the jacketing application. By considering these changes during the jacketing design, the jacketed section is ensured to achieve adequate shear and axial load strength.

Except for such brittle damages, jacketing is applied for elements with inadequate bending capacity or ductility. In this way, strength of the columns displaying a splice failure as a result of bending can also be improved. Jacketing of the columns has the best result when it is implemented at 4 sides of the column. Where necessary, confinement at 3 sides can also provide adequate performance. However, it is not generally recommended to implement the jacketing at 1 or 2 sides. Because, with such jacketing applications, no significant changes take place in the confinement characteristics of the member.

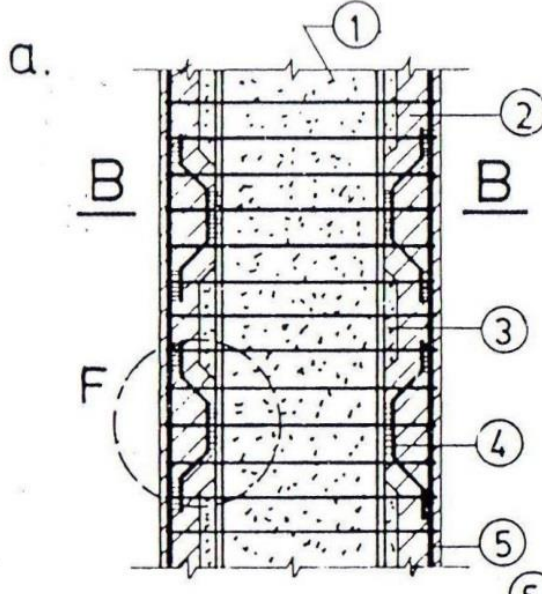

(5) b.

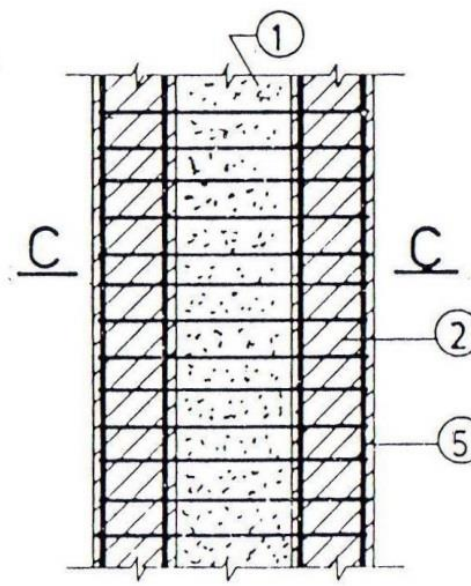

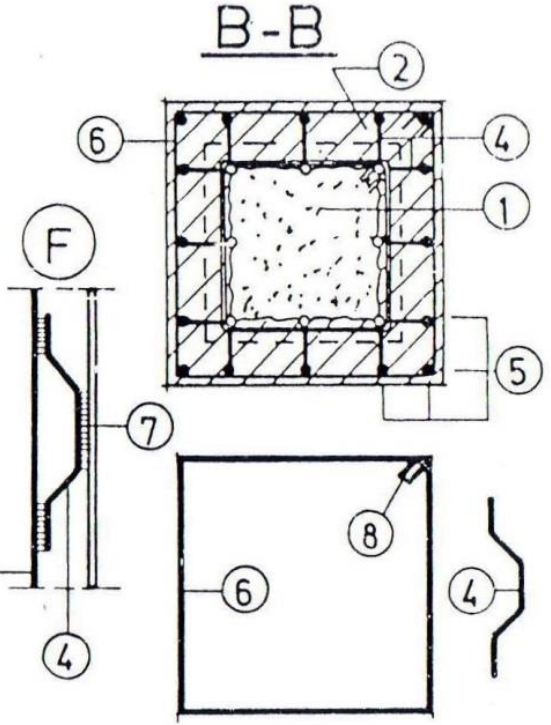

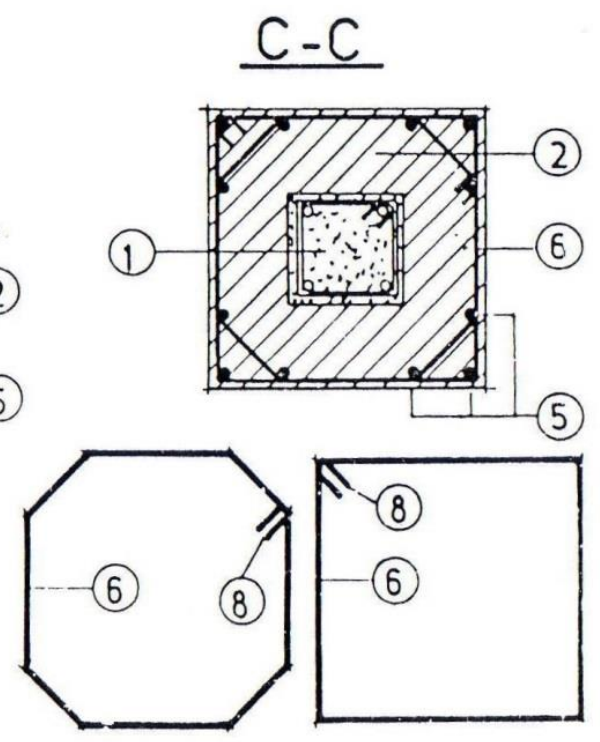

Figure 2.4. Connection of the old to the new reinforcement of the $R / C$ jacket: a) protection of new bar against buckling with welding; b) protection of new bar against buckling with octagonal ties; 1- existing column, 2- jacket, 3-key, 4-bent bars, 5-added reinforcement, 6-ties, 7-welding, 8-alternating corners), (P.Gavrilovic [15]) 


\subsubsection{Steel jackets}

Jacketing with steel elements is a practical method used frequently for various applications. A typical steel jacketing application is presented in Figure 2.5.

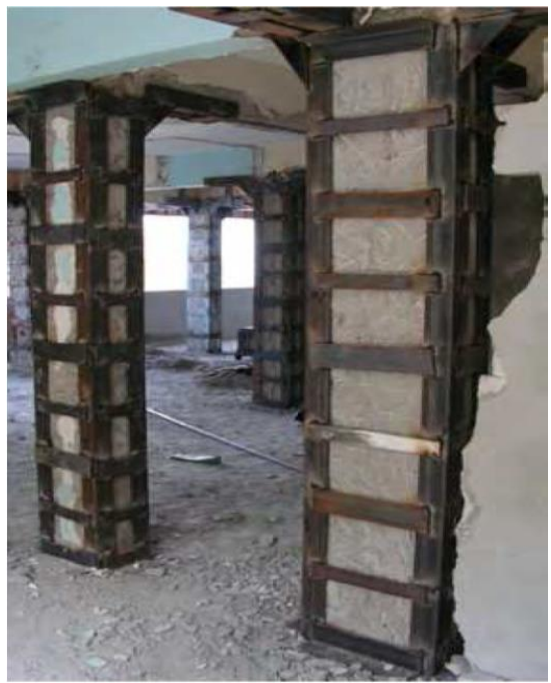

Fig.2.5. Steel jacketing applied to $R C$ columns(M.N.Fardis, [12])

Steel jacketing can readily be used to especially enhance the shear strength of reinforced concrete elements. Located at the corners of an element, Lprofiles are coupled by means of steel plates and confined. With the maintenance of continuity between storeys, steel jacketing can also be used to increase the bending strength. In addition, the maintenance of adequate strength between the steel element and reinforced concrete element is inevitable for the improvement of bending capacity.

\section{REPAIR AND STRENGTHENING OF BUILDINGS USING TRADITIONAL MATERIALS}

The aim of the repair and strengthening is to modify the seismic demands, and/or the capacities, so that all relevant elements of the strengthened building fulfil the general verification inequality, at all performance levels ("Limit States") under the corresponding seismic action (Figure 3.1) (Folić, R., Zenunović, D. Liolios, A., 2014).

Each strategy may be implemented by using more repair and strengthening techniques. All of them have their own advantages and drawbacks, scope and limitations of use and fit better in one of these strategies

The choice of the technique depends on many factors, such as:

- The locally available materials and technologies

- Cost consideration

- The disruption of use it entails and the duration of the works

- Architectural, functional and aesthetic considerations or restrictions, etc.

\subsection{Column strengthening}

Usually, the purpose of column strengthening is to improve earthquake resistance of damaged or undamaged buildings. In addition, in the case when, during the construction phase, there is failure of concrete or any other substantial material in reaching the required quality according to the design, strengthening of specific structural members will be applied. Increased resistance of columns means increased column flexural and shear strength, improving column ductility by applying different techniques of their strengthening (Folić, R., and al, 2015).

In the case of damaged columns, depending of the degree and type of damage, different techniques may be applied, such as resin injection, removal and replacement or jacketing.

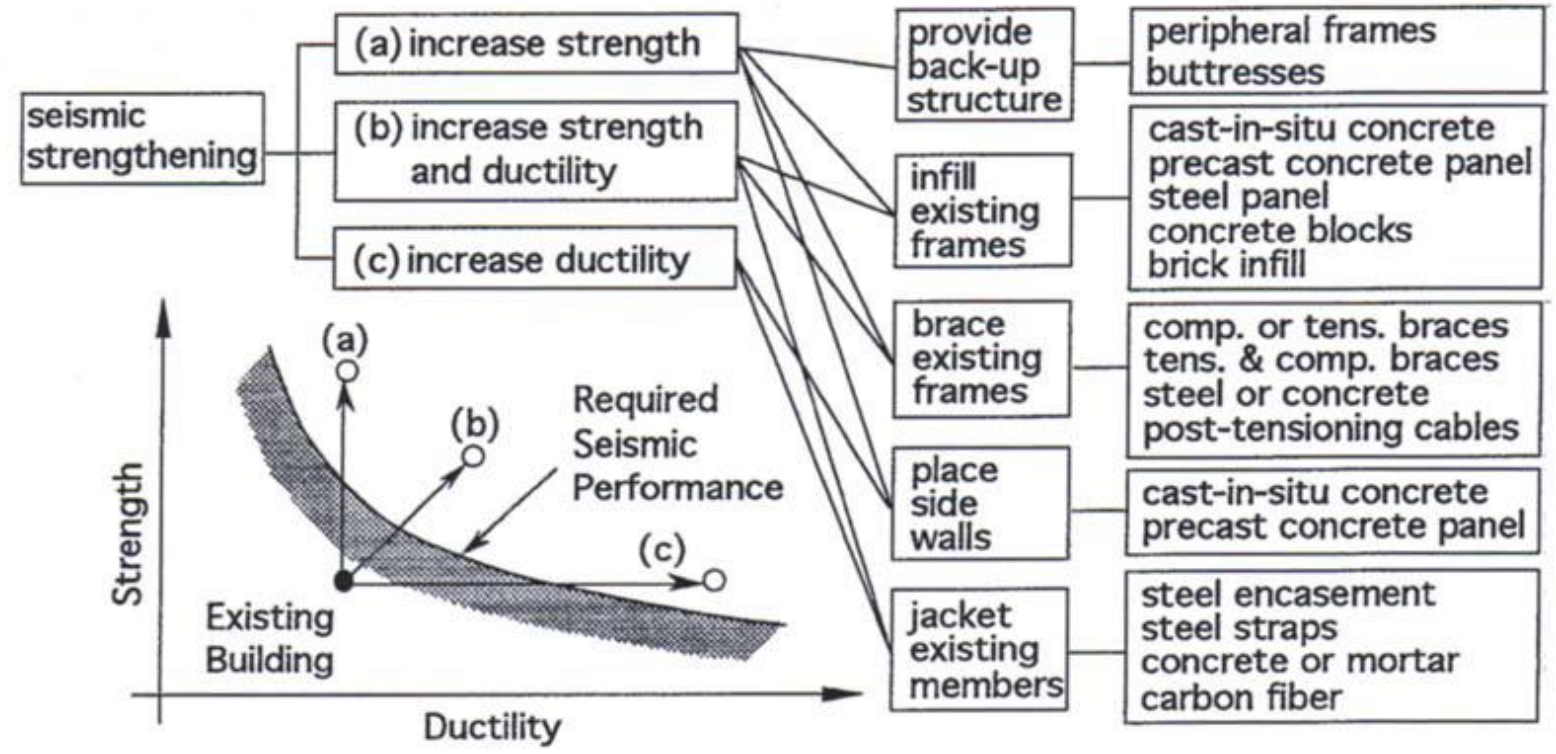

Figure 3.1. Strengthening strategies 


\subsubsection{Reinforced concrete jacketing of columns}

$\mathrm{R} / \mathrm{C}$ jackets are applied in the case of serious damage or inadequate seismic resistance of the column (including here failure of quality of concrete used on the site during construction). Depending on the existing local conditions, jackets are applied along the perimeter of the column, which is the ideal case, or sometimes on one or more sides.

In the case where the jacket is limited to the storey height, an increase in the axial and shear strength of the column is achieved with no increase in flexural capacity at the joints. Therefore, it is recommended that the jackets protrude through the ceiling and the floor slabs of the storey where column strengthening is necessary (Figure 3.2).

\subsubsection{Detailing of RC Jackets}

The concrete overlay of the jacket should be at least 75-100 mm, to provide sufficient cover of the new reinforcement and space for $135^{\circ-h o o k s}$ at the tie ends (Fig. 3.2(a)). For this range of thickness, shotcrete is more convenient. Thicker overlays are normally cast-inplace.

- In order to increase the moment resistance of vertical elements, longitudinal reinforcement should be continued to the adjacent storeys through the holes or slots in the slab. To avoid perforating the beams on all sides of the cross-section, jacket bars continuing through the slab should be concentrated near the corners of the new section, often in bundles (Fig.3.2. (b) and (c)). Jacket vertical bars may be anchored into a foundation element either:

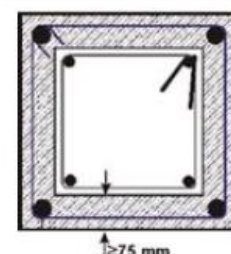

(a)
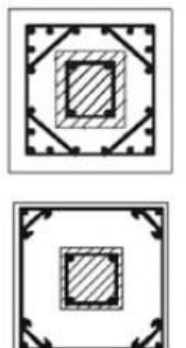

(b)
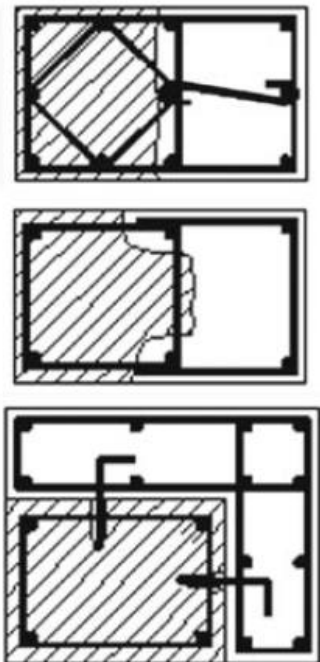

(f)

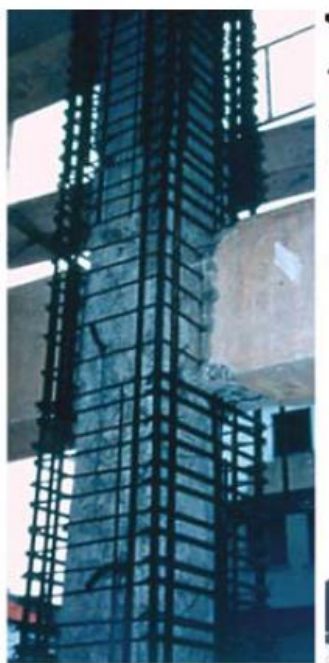

(c)

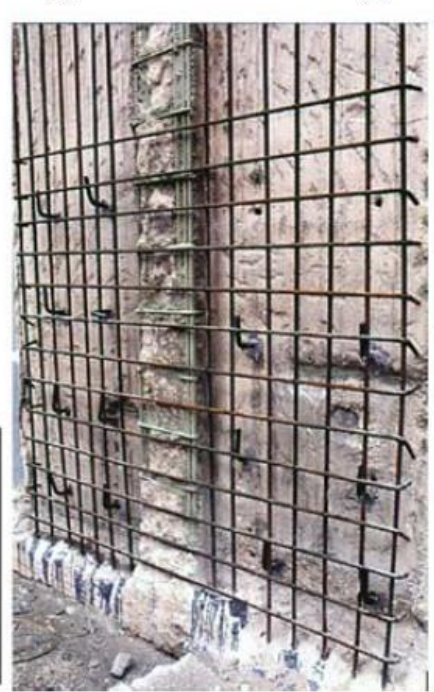

(g)

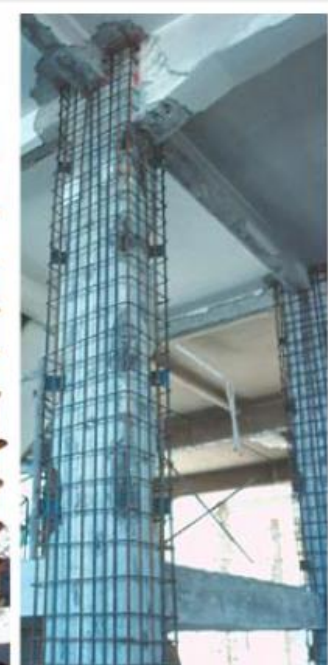

(e)

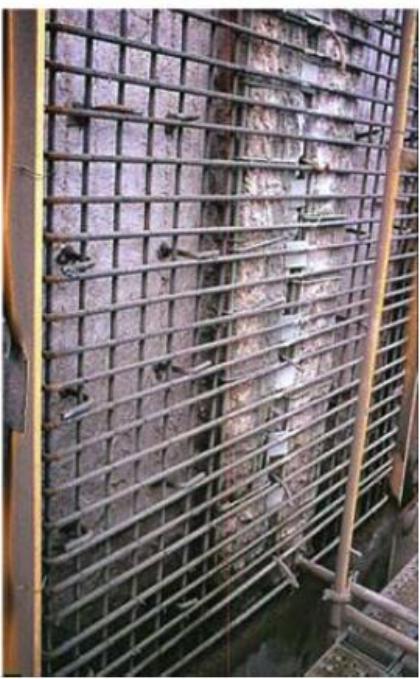

Figure 3.2. Concrete jackets in columns: a) the simplest case b) jacket bars bundled near corners, engaged by cross-ties or orthogonal tie c) jacket bars bundled at corners, dowels at interface with old column d) U-bars welded to corner bars e) steel plates welded to corner bars f) one-or two-sided jackets g) one-sided concrete overlay with single curtain of two way reinforcement at exterior face of perimeter walls, (M,Fardis[12]) 
- by enlarging the foundation element to accommodate anchorage of the jacket bars in the new concrete there (possibly increasing, at the same time, the capacity of the foundation element to meet the larger moment demands from the jacketed vertical member), or

- by fastening (e.g., through epoxy) starter bars within vertical holes drilled in the foundation element, to be lap-spliced with the jacket vertical bars outside the plastic hinge that may form at the bottom of the retrofitted element.

\subsubsection{Strengthening of columns with steel profile skeleton}

Steel profile skeleton jacketing consists of four longitudinal angle profiles placed one at each corner of the existing reinforced concrete column and connected together in a skeleton with transverse steel straps (Figure 3.3). In general, an improved ductile behaviour and an increase of the axial load capacity of the strengthened column is achieved. However, the stiffness remains relatively unchanged.

Steel jackets are more expensive than concrete ones. However, their technology is simple, familiar to the construction industry and readily available almost everywhere. So, it is the technique of choice for nonengineered emergency strengthening even hours after a damaging earthquake, to prevent the collapse of heavily damaged buildings or give back to use moderately damaged ones during the aftershock period. Detailed assessment and retrofit design may take place afterwards. The steel jackets may be removed when retrofitting is implemented, or incorporated in a concrete jacket (as in Fig. 3.4 (a)).
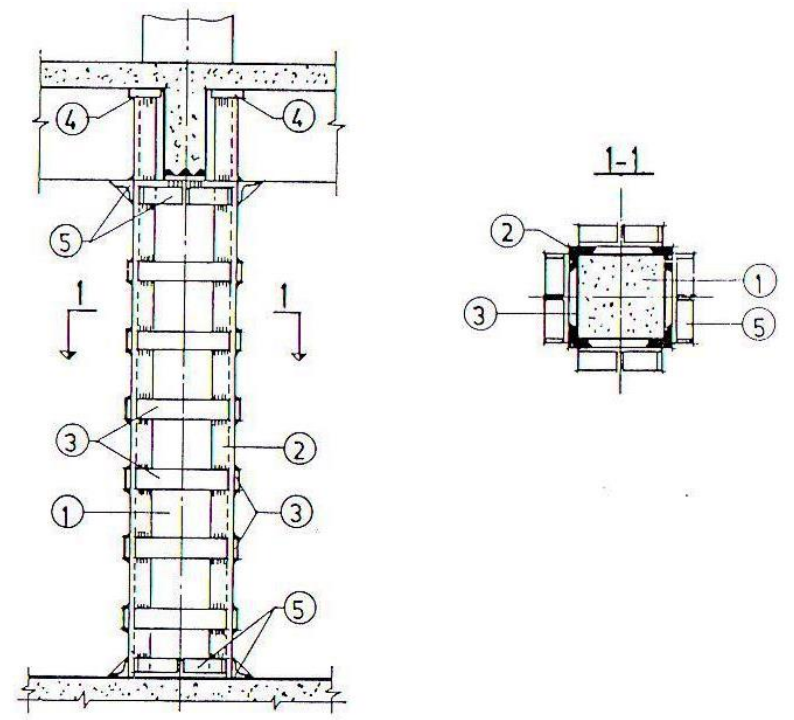

Figure 3.3. Strengthening of column with steel profiles at each corner; 1-existing column, 2-steel angle profile,

3-steel plate, 4-supporting plate, 5-angle profile. (P.Gavrilovic, [15])

\subsection{Beam strengthening}

The aim of repair and/or strengthening of beams are to provide adequate strength and stiffness of damaged or undamaged beams, which are deficient, to resist gravity and seismic loads. It is very important that the rehabilitation procedure chosen provides proper strength and stiffness of the beams in relation to adjacent columns in order to avoid creating structures of the "strong girder - weak column" type which tend to force seismic hinging and distress into the column, which must also support major gravity loads.

As in the case of columns, depending on the degree of damage in the beams, several techniques are applied, such as resin injections, glued metal or FRP sheets, removal and replacement of $R / C$ jackets.

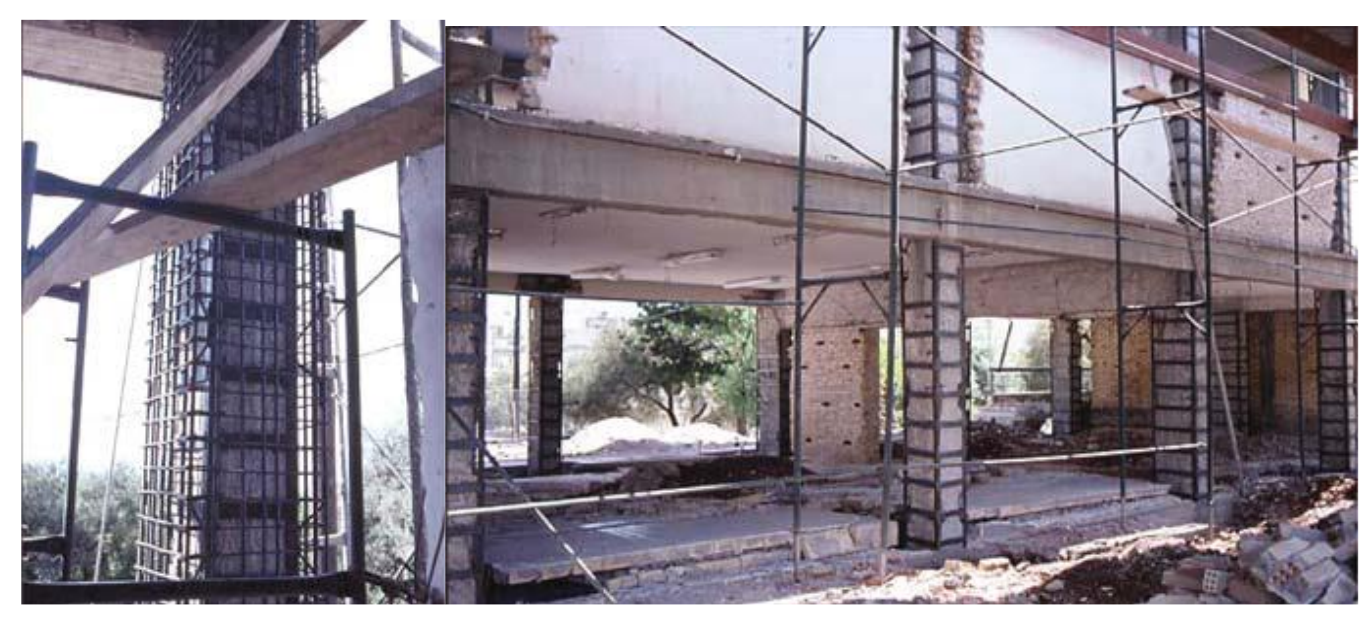

(a)

(b)

Figure 3.4. Steel jackets built-up in situ with corner angles and horizontal straps 


\subsubsection{Reinforced concrete strengthening and jacketing of beams}

Reinforced concrete jackets can be applied by adding new concrete to one, three or four sides of the beam. Within the same technique, one should also include strengthening of the tension or compression zone of a beam through the concrete overlays. In order to enable force transfer between old and new concrete, roughening of the old concrete is required, as well as welding of connecting bars to the existing and new reinforcement bars.(Cvetanovska 2000)

Reinforced overlays on the lower face of the beam (Figure 3.5) can only increase the flexural capacity of the beam. Existing reinforcement is connected to the new one by welding.

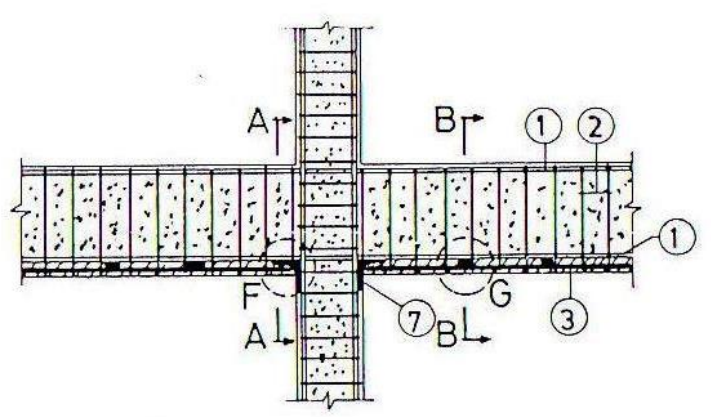

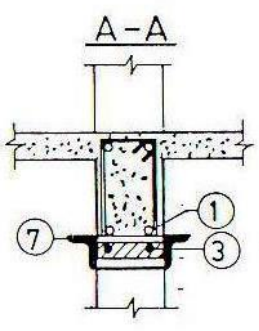

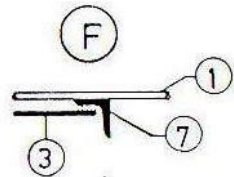

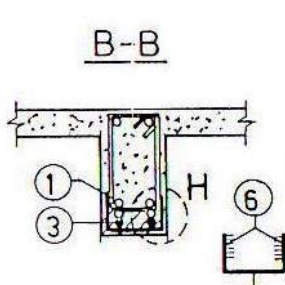

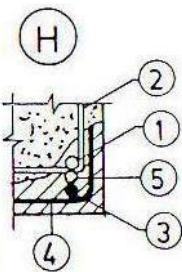

(4)
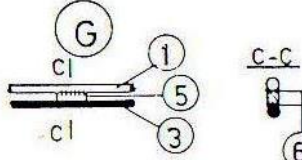

(6)
Figure 3.5. Strengthening of a beam on the lower face; 1-existing reinforcement, 2-existing stirrups, 3-added longitudinal reinforcement, 4-added stirrups, 5-welded connecting bar, 6-welding, 7-collar of angle profiles. (P.Gavrilovic,[15])

Jacketing on all four sides of the beams is the most effective solution. The thickness of the concrete which is added to the upper face is such that it can be accommodated within the floor thickness $(50-70 \mathrm{~mm})$. The placement of the ties is achieved through holes which are opened in slab at closely spaced distances, which are used for pouring the concrete. The longitudinal reinforcement bars of the jacket are welded to those of the old concrete (Figure 3.6)
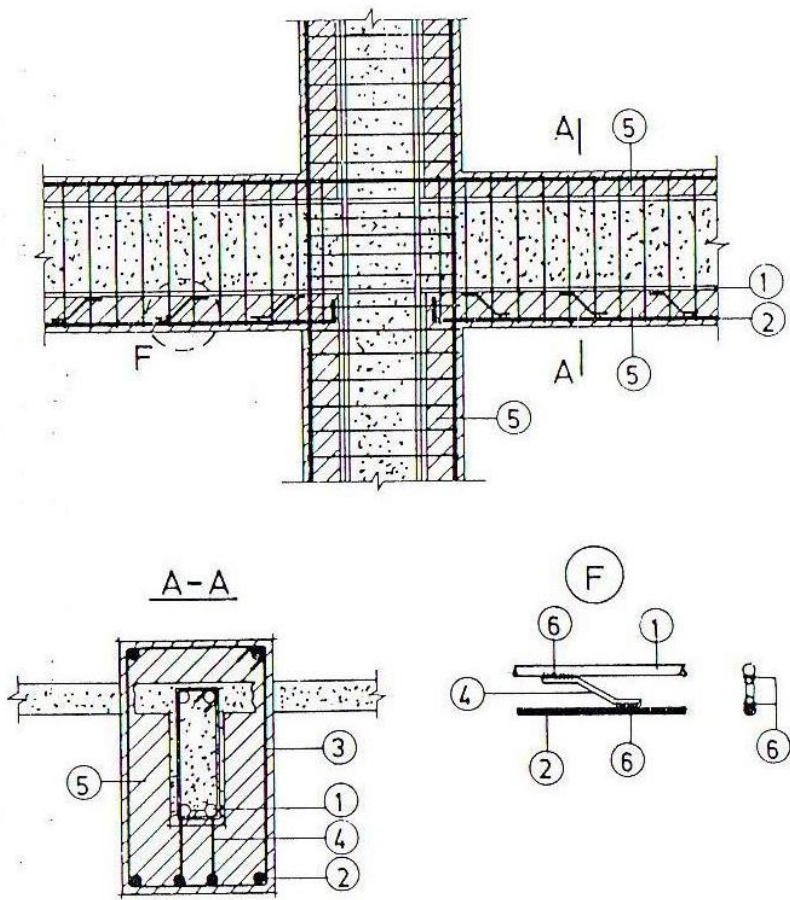

Figure 3.6. Jacket on four sides of a beam; 1-existing reinforcement, 2-added longitudinal reinforcement, 3-added stirrups, 4-welded connecting bar, 5-concrete jacket, 6-welding (P.Gavrilovic, [15])

Jackets on the three sides of the beam are used to increase flexural and shear capacity of the beam for vertical loading, but not for seismic actions, given that strengthening of the load-bearing capacity of the section near the supports is impossible.

\subsection{Shear wall strengthening}

Due to their great stiffness and lateral strength, shear walls provide the most significant part of the earthquake resistance of the building structure. Therefore, several damaged, poorly designed or constructed shear walls must be repaired or strengthened to significantly improve the structure's strength for seismic force. As in the case of columns and beams, here, shear wall strengthening can be done by using the epoxy resin and R/C jacketing technique.

\subsubsection{Reinforced concrete jacketing of shear walls}

When the original strength of the damaged or poorly constructed wall is insufficient, thickening the wall with reinforced concrete should be applied. There are different ways to add strength to an existing concrete shear wall (Figure 3.7). Shotcrete is a frequently used technique in strengthening concrete shear walls. 
a.

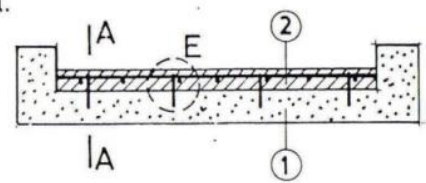

b.
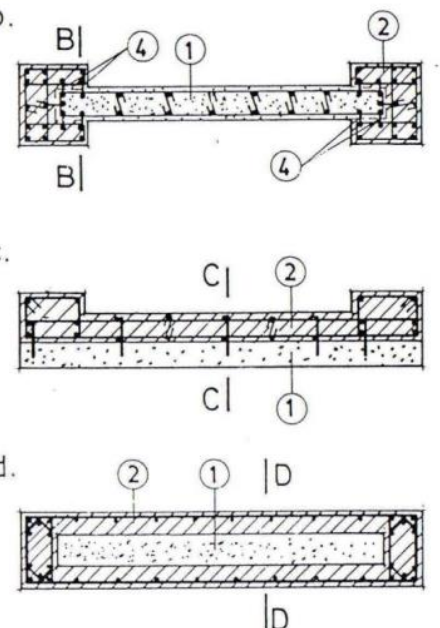

(2)

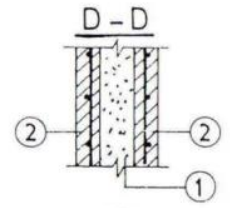

(E)

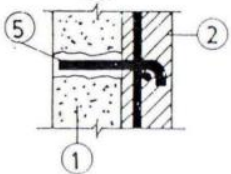

Figure 3.7. Strengthening the shear wall with $R / C$ jacket; 1-existing wall, 2-added wall, 3-added columns, 4-welding, 5-epoxied bar. (P.Gavrilovic [15])

\section{REPAIR AND STRENGTHENING BUILDINGS USING INNOVATIVE MATERIALS}

\subsection{Fibre Reinforced Polymers (FRP)}

FRP composites comprise fibres of high tensile strength within a polymer matrix. The fibres are generally carbon or glass, in a matrix such as vinyl ester or epoxy. These materials are manufactured to form plates under factory conditions, generally by a pultrusion process.

The primary materials in the composite are the reinforcement fibre and the polymer matrix. Other materials are incorporated in the composite but they are of less significance in terms of both effect on cost and effect on properties, although the term polymer composites includes both thermosetting and thermoplastic resins.
The most commonly used thermosetting resins in composites are polyester, urethane methacrylate, vinylester, epoxy and phenolic. They are isotropic materials which allow load transfer between fibres, but they perform several other things. The matrix protects notch-sensitive fibres from abrasion and it forms a protective barrier between the fibres and the environment, thus preventing attack from moisture, chemicals and oxidation. It also plays an important role in providing shear, transverse tensile and compression properties. The thermomechanical performance of the composite is also governed by the matrix performance.

Reinforcement fibres are qualified in three main families of glass, aramid and carbon. There are other fibres, but they are relatively insignificant. The most important property of the fibres is their elastic modulus, and the fibres must be significantly stiffer than the matrix which allows them to carry most of the stress. Consequently, they must also be of high strength. Reinforcements are available in a variety of configurations of which there are three main categories:

- Unidirectional, in which all the fibres lie in one direction.

- Bidirectional, in which the fibres lie at $90^{\circ}$ to one another. This is achieved either by the use of woven fabric, non-woven fabric or by the use of separate layers of fibres each unidirectional, but successively laid at $90^{\circ}$.

- Random, in which the fibres are randomly distributed and are in-plane.

Stress-strain fibre behaviour is different for every type of fibre. (Fig. 4.1). Different FRP shapes (Fig. 4.2) and Different material properties are given in Table 4.1 $[7,8]$.

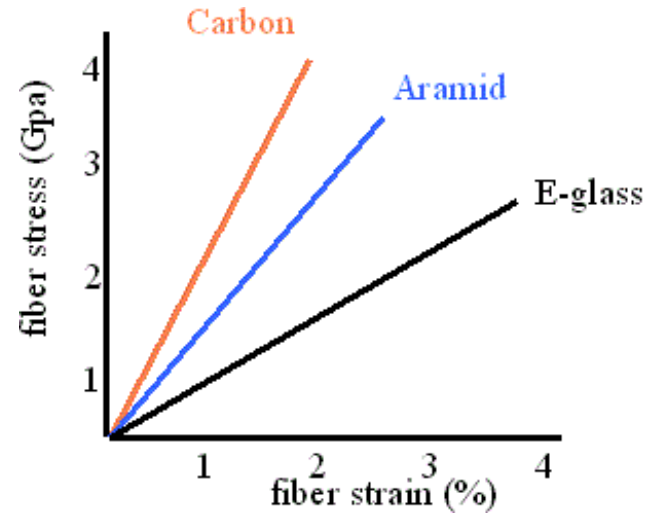

Figure 4.1. Stress- strain fibre behaviour (A. Prota, after [20])

Table 4.1. FRP materials - Fibre comparison

\begin{tabular}{|c|c|c|c|c|}
\hline & Strength & Modulus & $\begin{array}{c}\text { Moisture and } \\
\text { chemical resistance }\end{array}$ & Cost \\
\hline Carbon & High & High & Excellent & High \\
\hline Aramid & High & Intermediate & Good & High \\
\hline E-Glass & High & Low & Low & Low \\
\hline
\end{tabular}




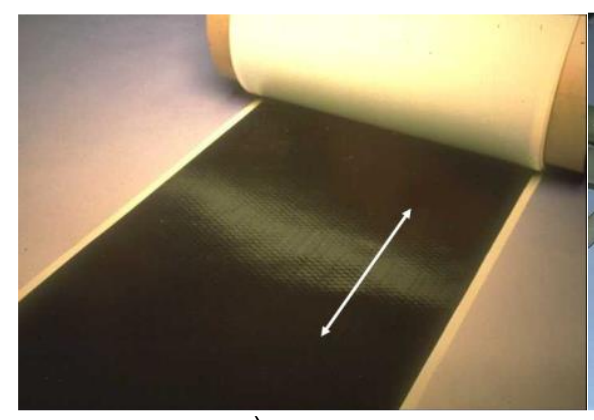

a)

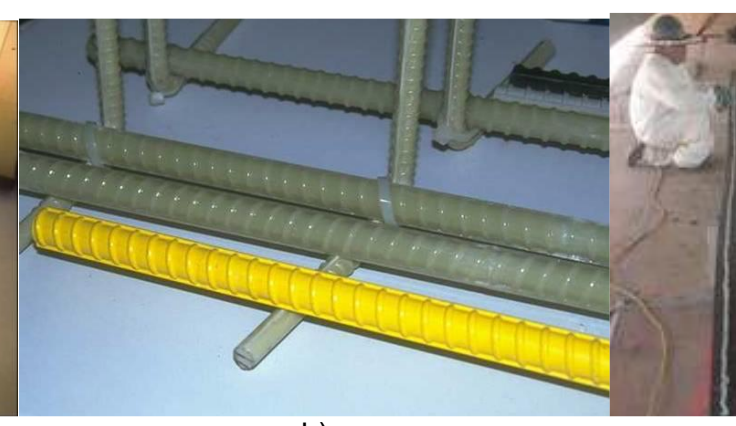

b)

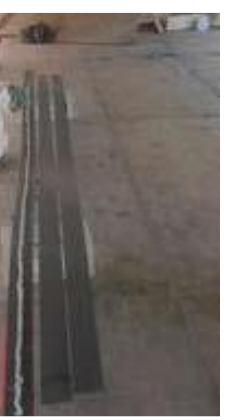

C)

Figure 4.2. Different FRP shapes a) sheet b) bars c) pre cured laminate (A. Prota, [20])

\subsection{Confinement strengthening}

Confinement strengthening (Figure 4.3 ) consists of:

(1) Cleaning and repair

(2) Primer

(3) Adhesive

(4) FRP strips

(5) Last adhesive layer

Fibre polymer fabrics that can be used to improve bending, shear and axial capacities of the columns and beams may be manufactured from various materials such as carbon, glass and aramid without an increase in the volume of the strengthened member. In addition, significant improvements can be achieved in the capacity and ductility characteristics of the element. In Figure 4.4, beam strengthening in an existing structure is presented.

These materials may be used for numerous purposes such as enhancement of the flexural capacity of floor slabs and improvement of shear capacity of beams, columns, joints and shear walls (Fig. 4.5 and Fig. 4.6)

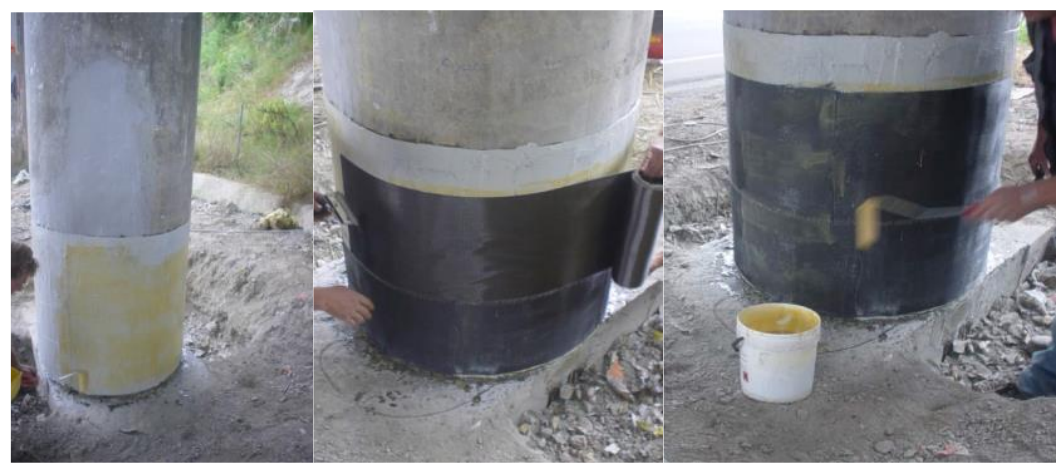

Figure 4.3. Confinement strengthening (Di Ludovico M. [21])

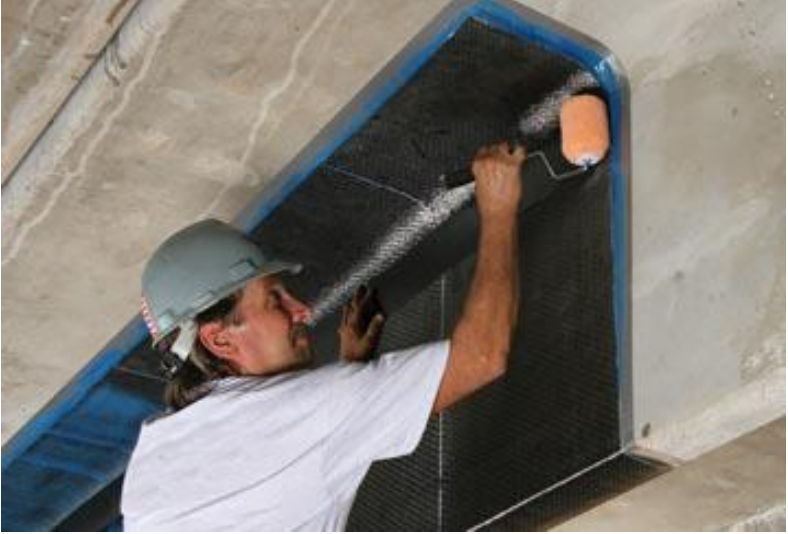

Figure 4.4. FRP strengthening of a beam (CNR-DT, [8])

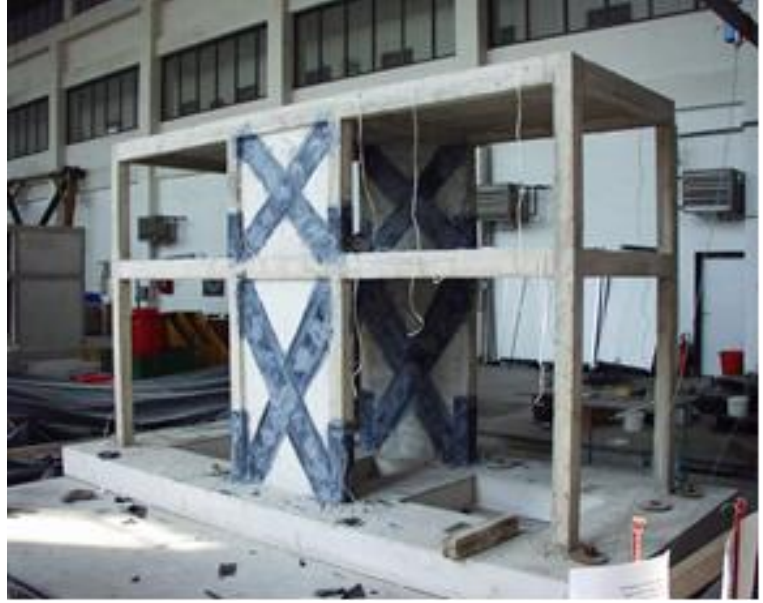

Figure 4.5. Completed model with added carbon fibres (NATO SfP 977231 [29]) 


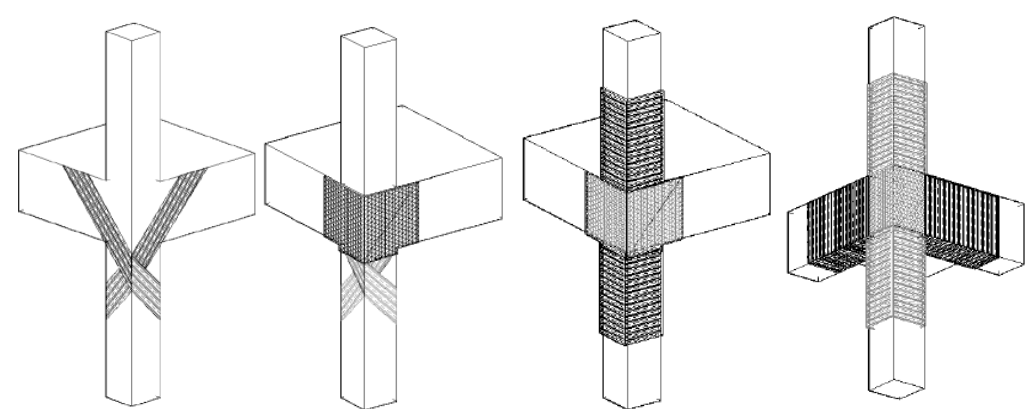

Figure 4.6. Seismic strengthening of external joints using CFRP sheets, (Ozcebe, G.[5])

\section{CONCLUSION}

The conclusion is given through comparative evaluation of the local retrofit strategies given in table 5.1 .

Table.5.1. Comparative evaluation of the local retrofit strategies

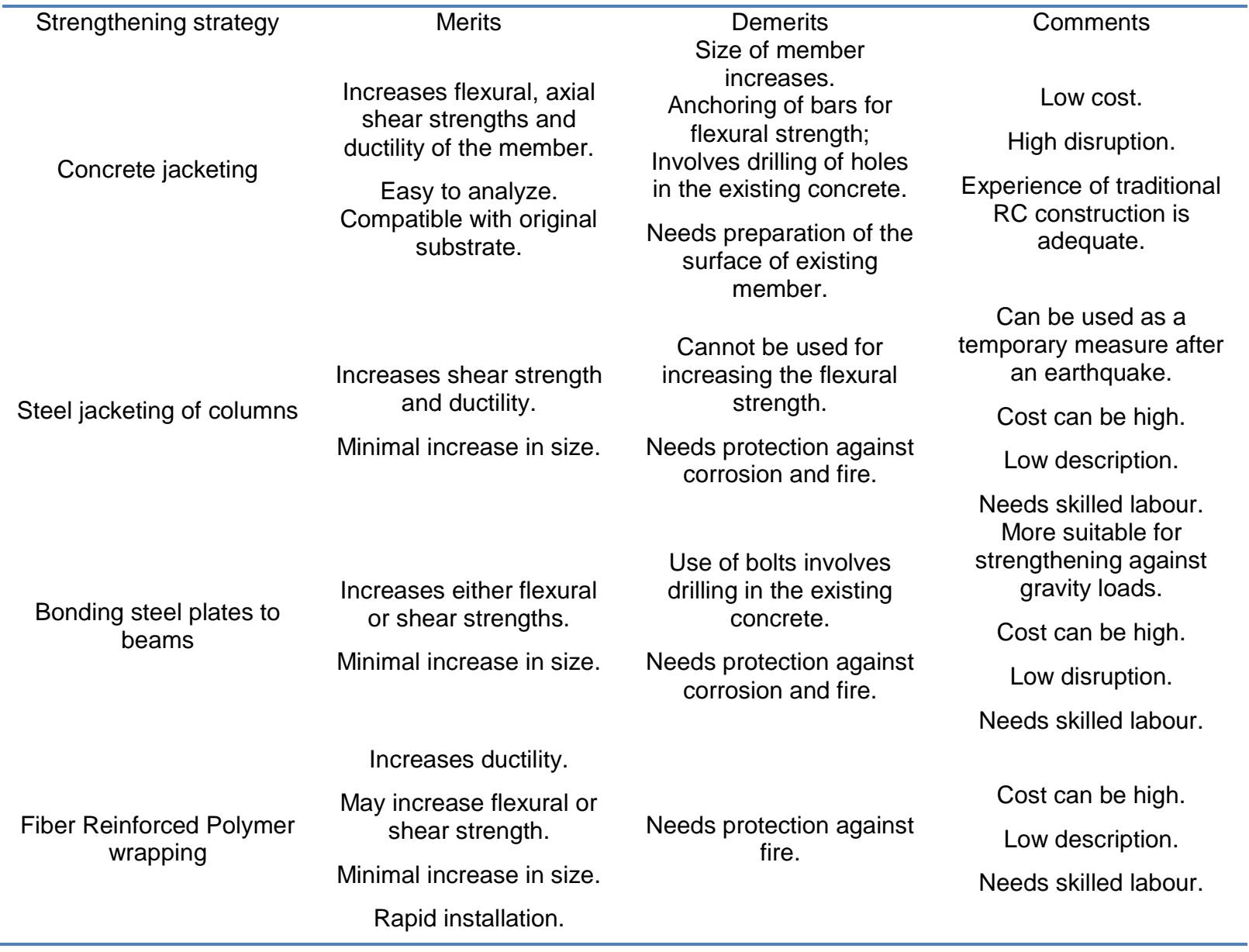


[1] Eurocode 8: Design of Structures for Earthquake Resistance - Part 1: General Rules, Seismic Actions and Rules for Buildings.

[2] CEN 2004, European Standard EN 1998-3: 2005 Eurocode 8: Design of Structures for Earthquake Resistance. Part 3: Assessment and Retrofitting of Buildings.

[3] Folić, R., Zenunović, D. Liolios, A., “ Recommendation for seismic apgrading of damaged RC Structures", Int Conf. Structural Faults and Repair" June 2014, Edinburgh, Scotland, Proc. Editor: Professor M C Forde

[4] Golubka Nechevska-Cvetanovska, "Non-Linear Analysis and Design of RC Cross-Section Resistance of RC Buildings", published September 1998.

[5] Ozcebe, G., Ersoy, U., Tankut, T,, Akyuz, U., and Erduran, E., 2004. "Rehabilitation of Existing RC Structures Using CFRP Fabrics", Proceedings of the 13th World Conference on Earthquake Engineering, Vancouver, Canada, Paper No. 1393.

[6] Earthquake-Resistant Construction of Adobe Buildings (available in Spanish and English) EERI Publication \# WHE-2006-01 (published on the web in 2003; hard copy in 2006).

[7] M. DI ludovico, A. Prora, G.Manfredi and E.Gosenza, "Seismic Strengthening of an Underdesign RC Structure with FRP", Department of Structural Engineering, University of Naples Federico II, Naples, Italy, Published online 24 August 2007 in Wiley InterScience;

[8] CNR-DT 200/2004. Guide for the Design and Construction of Externally Bonded FRP Systems for Strengthening, 2004 (Downloaded free from: http://www.cnr.it/sitocnr/ICNR/Attivita/Normazionee Certificazione/NormazioneeCertificazione file/struzioniCNR DT200 2004 eng.pdf).

[9] Abbas Moustafa "Earthquake_Resistant Structures-Design, Assessment and Rehabilitation", Published online February 2012, published in print edition February 2012.

[10] "Handbook on Seismic Retrofit of Buildings", April 2007, edited by Indian Institute of TechnologyMadras.

[11] Barbara Ferracuti, Marco SAVOLA, Roberto FRANCIA, Rui PINHO, Stelios ANTONIOU "Pushover Analysis of FRP-Retrofitted Existing RC Frame Structures", University of Patras, Patras, Greece, July 2007.

[12] Michael_N.Fardis, "Seismic Design, Assessment and Retrofitting of Concrete Buildings, Department of Civil Engineering, University of Patras, Greece, 2009.

[13] L C Hollaway and M B Leeming, "Strengthening of Reinforced Concrete Structures Using ExternallyBonded FRP Composites in Structural and Civil Engineering", published in North and South America by CRC Press LLC, 2000 Corporate Blvd, NW.

[14] L.C. Hollaway and J.G. Teng, "Strengthening and Rehabilitation of Civil Infrastructures Using FibreReinforced Polymer (FRP) Composites" published 2008, Woodhead Publishing Limited and CRC Press LLC.
[15] Gavrilovic, P. "Repair and Strengthening of Building Structures" lecture notes, Institute of Earthquake Engineering and Engineering Seismology, Skopje 2005.

[16] Yan Z, Pantelides CP (2007), “Design-Oriented Model for Concrete Columns Confined with Bondea FRP Jackets or Post-Tensioned FRP Shells", In: Triantafillou TC (ed) 8th International Symposium on Fiber Reinforced Polymer Reinforcement for Concrete Structures (FRPRCS-8), Patras, GR, paper 6-1.

[17] Jones, I.A; Owen, M.J.; Middleton, V; “Integrated Design and Manufacture Using Fibre-Reinforced Polymeric Composite", CRC Press LLC, Cambridge, England, 2000.

[18] http://www.mdacomposites.org/Manufacturing.htm, Market Development Alliance of the FRP Composites Industry, Copyright 2000-2001 Market Development Alliance of the FRP Composites Industry.

[19] Ko, Frank K., Du, George W., "Handbook of Composites-Textile Preforming", Chapman and Hall, 1998, London, England.

[20] Andrea Prota "Innovative Building Materials", lecture notes, Department of Structural Engineering, University Federico II, Naples, 2014.

[21] $\mathrm{Di}$ Ludovico M. "Design and Retrofit of $R C$ Constructions", lecture notes, Department of Structural Engineering, University of Naples Federico II, 2013.

[22] Mazzolani "Protection of Historical Buildings", PROHITECH 09, 2009 Taylor \& Francis Group, London.

[23] Folić, R., Radonjanin, V., Prokić, A., Malešev, M.: Earthquake dame to $\mathrm{RC}$ bridges and review of recommendation for its repair and strengthening (ID 1594-Folic), 16th European Bridge Conference, $23^{\text {rd }}-25^{\text {th }}$ June 2015, Edinburgh, Scotland, Proc. Editor: Professor M C Forde, pp.18. ,ISBN No: 0947664-78-4;

[24] N. Pojani (2003). "Seismic Engineering". Published at TOENA, Tirana, Albania.

[25] A. K. Chopra (2003). "Dynamic of Structures" $2^{\text {nd }}$ ed. Theory and Application to Earthquake Engineering. Prentice Hall, New Jersey.

[26] T. Paulay and M. J. Priestly (1992). "Seismic Design of Reinforced Concrete and Masonry Structures". Wiley \& Sons, ISBN 0 - 471 - 54915 - 0.

[27] G. Necevska-Cvetanovska and R. Petrusevcka (2000). "Methodology for Seismic Design of R/C Building Structures ". 12WCEE.

[28] European Committee. "Eurocode - 2: Design of concrete structures".

Part 1-1: General rules and rules for buildings. English version, December 2004.

[29] "NATO SfP 977231 Project: "Seismic Assessment and Rehabilitation of Existing Buildings", NATO Science Series. 


\section{REHABILITATION OF RC BUILDINGS IN SEISMICALLY ACTIVE REGIONS USING TRADITIONAL AND INNOVATIVE MATERIALS}

\section{Golubka NECHEVSKA-CVETANOVSKA} Artur ROSHI

The field of research in the frames of this paper will be Application of Traditional and Innovative Materials for Repair and Strengthening of RC Buildings in Seismically Active Regions. The need for repair and strengthening of RC buildings and their structural elements occurs when their elements are insufficiently strong, stiff and/or ductile out of different reasons or due to slighter or more severe damages most frequently caused by earthquakes. Within the frames of this paper, special emphasis will be put on RC buildings where, during construction, the built-in concrete fails to achieve the designed concrete class and/or buildings that cannot satisfy the required strength, stiffness and deformation characteristics particularly in earthquake conditions due to built additional storeys or enlargements. In these cases, it is necessary to take measures for repair and strengthening of both individual structural elements and whole structures using traditional and Innovative Materials.

Key words: Concrete quality, Rehabilitation, Repair and Strengthening, Seismically active regions, Traditional and Innovative Materials, Concrete jacketing, FRP

\section{REHABILITACIJA ARMIRANOBETONSKIH (AB) KONSTRUKCIJA U SEIZMIČKIM USLOVIMA KORIŠĆENJEM TRADICIONALNIH I INOVATIVNIH MATERIJALA}

\section{Golubka NECHEVSKA-CVETANOVSKA Artur ROSHI}

Predmet ovog rada je primena tradicionalnih $i$ inovativnih materijala za sanacije i pojačavanje $A B$ konstrukcija u seizmički aktivnim regionima. Potreba za izvođenje sanacija i pojačavanja kod zgrada i elemenata i drugih objekata ukoliko elementi nemaju dovoljnu nosivost, krutost i/ili duktilnost usled toga da se u slučaju zemljotresa javljaju umerena ili ozbiljna oštećenja zavisno od snage i učestalosti zemljotresa. U okviru ovog rada, poseban naglasak je na $A B$ zgradama koje ne zadovoljavaju kvalitet ugrađenih materijala i građenja i ne zadovoljavaju nosivost, krutost i karakteristike deformabilnosti bitnih za uslove delovanja zemljotresa ili dodavanje novih spratova. U tim slučajevima potrebno je izvesti radove na sanaciji i pojačavanju na svakom od elemenata korišćenjem tradicionalnih i inovativnih materijala.

Ključne reči: Kvalitet betona, Rehabilitacija, sanacija i pojačavanje, Seizmički aktivna područja, Tradicionalni i Inovativni materijali, Betonska ojačanja preseka, Polimerom modifikovani materijali (FRP) 